liability of the supply authority ceases. Another difficulty is that the time of the peak load varies owing to the great increase in domestic water heaters and thermal storage apparatus which has recently occurred. In many places, when making a longterm agreement, no period of the day or night can now be regarded as 'off peak' and allowed for at a cheaper rate. A supply for a fixed number of hours per day at the lower rate can be arranged, but this is not so attractive to the consumer. Everyone agrees that standardization is desirable, but there are difficulties in the way until the many small undertakings in the country are amalgamated with the larger authorities. When this comes, a lowering of the tariffs will follow in the country districts, since the 'diversity' of the combined load will be increased and so less spare plant be required. A broader policy also can be adopted.

\section{Education of Unemployed in the United States}

Educational needs of unemployed young people are discussed in Bulletin, 1936, No. 18-3, entitled "Education for those out of School", recently published by a standing committee established two years ago by the United States Office of Education in cooperation with other Government agencies and educational leaders for the purpose of assisting communities and youth agencies, with the aid of youths themselves, to solve some of the problems overshadowing their outlook to-day (Washington, D.C. : Government Printing Office, 1936. 10 cents). This pamphlet, the third of a series of six bulletins issued by the committee, describes some of the plans that have proved serviceable to unemployed persons of ages 16-24 years. Of the twenty million persons of those ages in the United States, some four million are in full-time schools and colleges, nearly eight million are employed on full- or part-time jobs, and nearly five million are seeking employment.

ONe conclusion arrived at by the committee is that there is a large unsatisfied demand on the part of these young people, and especially girls, for training which will lead to, if it is not combined with, earning capacity. Another conclusion is that in the case of rural youth a combination of educational and recreational schemes is essential; neither the strictly educational nor the strictly recreational schemes have been found successful. Again, informal rather than formal procedures are desirable, and units of instruction and courses should be of short duration; for example, twelve to fifteen weeks to a unit with twohour meetings once or twice a week. Above all, instruction should have specific goals and arouse a sense of achievement or arrival at a determined destination, and work should be so planned as to give a sense of continuity. Particulars are given of numerous schemes of vocational training for out-ofschool youth which have been found to work well. The other bulletins of this series are entitled : how communities can help, leisure for living, vocational guidance for those out of school, finding jobs, and health protection.

\section{Scottish Technical Colleges}

Tне Royal Technical College, Glasgow, reviews, in its report on the work of the session 1935-36, its own progress since its constitution in 1886 by the amalgamation of Anderson's College with a number of other separate institutions. In these fifty years, the number of its day students has increased from 124 to 1,001 and its gross income from $£ 9,248$ to $£ 81,837$. Among its more important developments during that time are the establishment of departments of architecture, textile manufacture, navigation, sugar manufacture, pharmacy and bakery, and the erection and equipment of new buildings at a cost of $£ 400,000$. Its counterpart in Edinburgh, the Heriot-Watt College, has far fewer day students (364) but its evening class students $(2,460)$ are nearly as many as those of the R.T.C. Both colleges co-operate with city and county education committees in regard to the provision in continuation schools of courses preparatory to college courses. The Edinburgh college, however, records a serious falling off in the number of students from city continuation schools, and attributes this decline to lack of interest on the part of employers.

\section{Heat and Power Station in Northern Russsia}

According to the Soviet Union Year Book Press Service, Grand Buildings, Trafalgar Square, W.C.2, plans have been completed for the building of a large heat and power station about twenty miles from Kotlas, a busy town in the northern province of the U.S.S.R. It will be built in virgin forest, near the site where building work is now proceeding in connexion with cellulose, chemical and wood-working enterprises for the Soviet timber and paper industry. This year the first section of the station with a capacity of $24,000 \mathrm{~kW}$. will be brought into operation. It will have an annual output of $1 \cdot 2$ million tons of steam. Fuel will be provided by gas generated by pitch, a by-product from the local timber and chemical industries. Four boilers will produce 60-80 tons of steam per hour, at a pressure of 35 atmospheres, the steam passing into turbines of $12,000 \mathrm{~kW}$. each. These boilers are fitted with special fuel jets for the new form of fuel. The turbines can run at various steam pressures, depending on the requirements of production.

\section{The Midwifery Service}

The annual report of the Central Midwives Board for the year ended March 31, 1936, has been published (London : H.M. Stationery Office. 2d. net). It shows that there were 62,064 women on the midwives roll, an increase of 3,100 on the total for the previous. year, although only a little more than a quarter of the total number of qualified midwives are actually engaged in the practice of their profession. The report states that during the year the Board approved a. final draft of new rules for training and examination, which has since been submitted to the Minister of Health. The report also includes notes on interesting decisions given by the Board during the year on midwifery etiquette and practice. 